\title{
ORIGINALS
}

\section{Storage of Acidophilic Granules in the Pituitary in Experimental Hyperglycaemia}

\author{
H. Stginer* and Chr. Hedinger \\ Departments of Pathology of the Universities of Zurich and Lausanne
}

Received: October 20, 1969

Summary. Pituitaries of Syrian hamsters with and without chronic hyperglycaemia were studied with morphometric and karyometric methods. The hyperglycaemic state was induced by low doses of alloxan, and maintained for 25 to 37 days. It had been potentiated in one group by a resection of at least $50 \%$ of pancreatic tissue prior to alloxan administration. A marked rise in the volume of the acidophils was found $(p<0.005)$. On the other hand, the karyometric studies revealed a definite diminution of the mean nuclear area of the acidophils in the diabetic animals, indicating decreased activity. The combination of an increase in mass of acidophils and a decrease in their nuclear activity supports the theory of an increased storage rather than hypersecretion of a hormone. The hormone which was stored in the acidophils is probably identical with growth hormone. If we consider the role of this hormone in carbohydrate and lipid metabolism, such a storage in chronic hyperglycaemia seems to be of importance.

Accumulation de granules acidophiles dans l'hypophyse en cas d'hyperglycémie expérimentale

Résumé. Nous avons étudié l'influence d'un état d'hyperglycémie chronique sur la morphologie hypophysaire avee des méthodes morphométriques et karyométriques. L'hyperglycémie était induite par de faibles doses d'alloxane et maintenue pendant 25 \& 37 jours. Dans un groupe, elle a été potentialisée par une pancréatectomie partiolle d'au moins $50 \%$, avant l'administration d'alloxane. Nous constatons une augmentation du volume des cellules hypophysaires acidophiles chez les animaux hyperglycómiques $(p<0.005)$. D'autre part, le volume des noyaux de ces cellules est nettement diminué, ce qui in- dique une réduction de l'activité nucléaire. La combinaison d'une augmentation de volume cellulaire et d'une réduction de l'activité nucléaire traduit une accumulation secondaire d'hormone plutôt qu'une hypersécrétion. Il s'agit probablement de l'hormone de eroissance, dont l'importanee dans le métabolisme des glucides et des lipides est bien connue.

Speicherung acidophiler Granula in der Hypophyse bei experimenteller Hyperglykämie

Zusammenfassung. Mit morphometrischen und karyometrischen Methoden haben wir die Bedeutung der Acidophilenvermehrung in der Hypophyse bei chronischer Hyperglykämie experimentell untersucht. Bei Goldhamstern wurde diese während 25-37 Tagen mit Alloxan. erzeugt. In einer Gruppe wurde die Alloxanwirkung potenziert durch vorherige partielle Pankreatektomie. In der Hypophyse war die Vermehrung des totalen Acidophilenvolumens ausgeprägt $(p<0.005)$. Hingegen waren durchschnittlich die Kerne dieser Zellform deutlich verkleinert. Diese Kombination von Kernverkleinerung und Volumenvermehrung weist auf erhöhte Hormonspeicherung hin und nicht auf Mehrsekretion. Wahrseheinlich ist das gespeicherte Hormon vorwiegend Wachstumshormon. Dessen Bedeutung für Zucker- und Fettstoffwechsel ist unbestritten und diese Speicherung scheint bei chronischer Hyperglykämie eine funktionell wichtige Bedeutung zu haben.

Key-words: Alloxan diabetes, pituitary and diabetes, growth hormone, morphometry, karyometry, chronic hyperglycaemia, free fatty acids, Syrian hamster.
In a morphometric study of pituitaries from patients with diabetes mellitus we observed a marked rise in the volume of the pituitary acidophils in cases of insulin-resistant diabetes and of lean diabetes with an absolute $\mathrm{B}$-cell deficiency in the islets of Langerhans [17]. On the other hand, in obese mild diabetes this change was much less impressive. The question remained whether this elevated total mass of acidophils was a primary lesion in lean diabetes or a secondary effect. Therefore we started the present investigation with karyometric and volumetric studies in the experimentally hyperglycaemic Syrian hamster.

\section{Material and Methods}

The aim was to produce a continuous hyperglycaemic state in hamsters with alloxan and to avoid general toxic effects by the diabetogenic agent. We chose

* Supported by grant $\mathrm{Nr} .3625$ of ,Schweizerischer Nationalfonds zur Förderung der wissenschaftlichen Forschung".
Syrian hamsters weighing $120-155 \mathrm{~g}$, and aged about 2 months; and divided these into 3 groups.

In group 1 ( 6 animals) at least $50 \%$ of the pancreas was resected 10 days prior to the injection of lower doses of alloxan. In group 2 (9 animals) the only treatment was injection of alloxan (the higher dose), 6 animals were used as controls. Since preliminary studies showed normoglycaemia in sham-partially-pancreatectomized animals, we have not included this series in this report. The animals which died before the end of the experimental period were not included in the results. Alloxan was injected intravenously (Sublingual vein) in a dose (see below in results section) which was just sufficient to produce glycosuria. Since it was only transient in many cases of group 2, we repeated the injections intraperitoneally $(2-5$ times) in appropriate doses. The last re-injection was done 2 days prior to the killing of the animals. Peroral instillation was tried in some cases, but the doses had to be quite high. 
After 27 to 36 days of hyperglycaemia, the animals were rapidly killed with ether after a short fasting period of about $1 \frac{1}{2} \mathrm{~h}$. The pituitaries were weighed, fixed in formol sublimate, embedded in paraffin and $3 \mu$-thick serial sections were stained with Pearse's trichrome method. The horizontal serial sections of 10 pituitaries were technically sufficient for stereologic measurements as proposed by Weibel $[20,21]$. We recorded: 1 . the whole mass of acidophils without trying to differentiate the 2 major forms [4]; and 2. the rest of the tissue together with the intercellular spaces. The number of recorded points was between 7000 and 20000 per pituitary.

In 13 pituitaries karyometric studies could be done. With an electronic microlength measuring instrument (Wild, Heerbrugg, Switzerland) the diameters of 40 successive nuclei of acidophils were measured on the din blue, Hematoxylin-eosin, Victoria blue (Ivic). Acells, well granulated and scarcely granulated B-cells and completely degranulated cells were counted separately. We tried to olassify 1000 islet cells per animal in this manner. Nuclear glycogen of the hepatocytes was shown with Best's stain in alcohol-fixed tissue. For determinations of glucose and free fatty acids (FFA) we used fluoride-oxalate blood aspirated terminally by cardiopuncture. Glycosuria was tested with Tes-Tape ${ }^{\circledR}$-Lilly.

\section{Results}

Generally, glucosuria occured after an injection of $50 \mathrm{mg}$ alloxan per $\mathrm{kg}$ body weight; but was only transient in many cases of group 2, and therefore subsequent injections had to be performed as shown in the methods section. Generally, in the hyperglycaemic
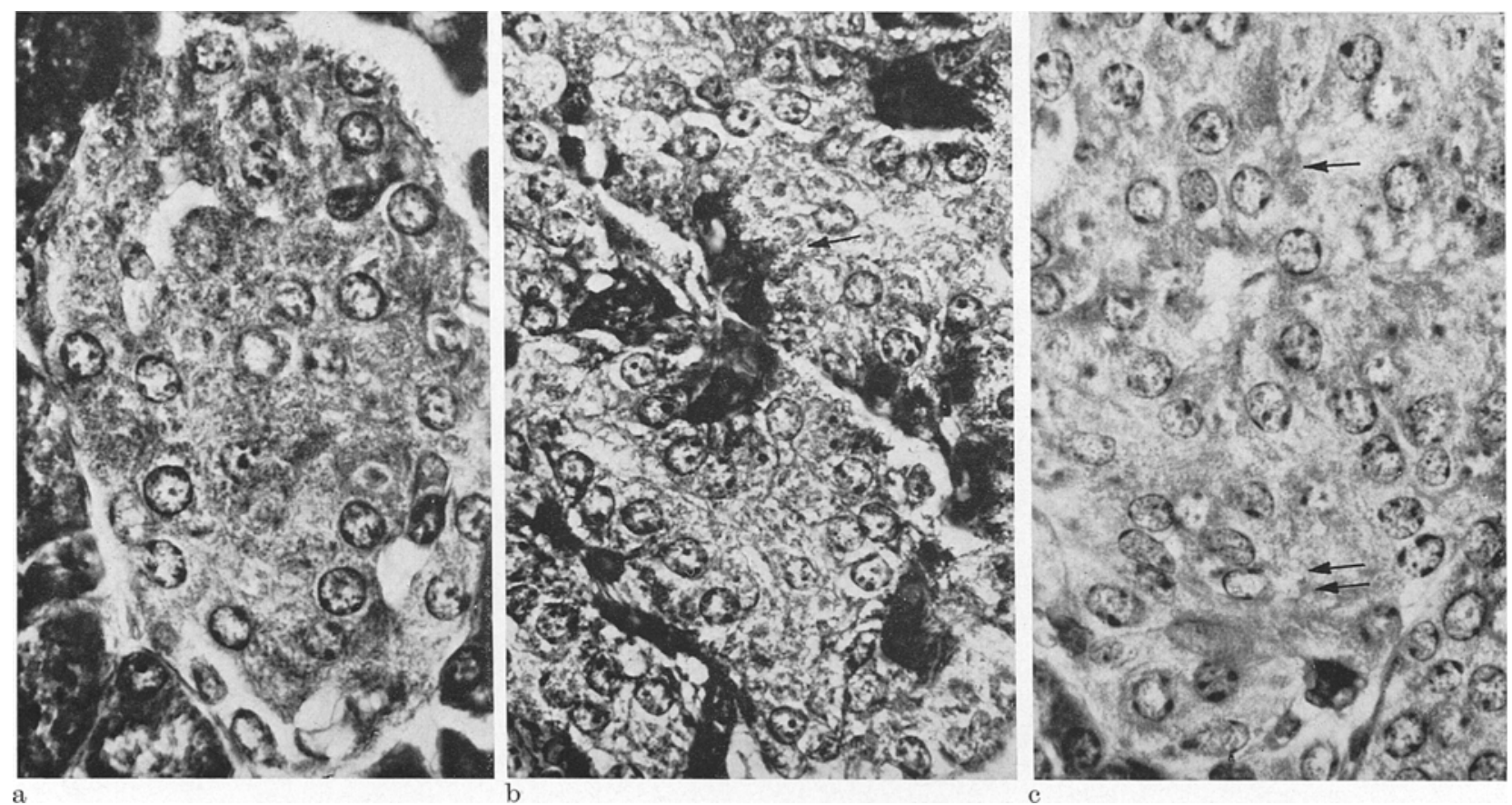

Fig. 1 a. Full B-cell granulation in control animal (no 2, glycaemia $101 \mathrm{mg} / 100 \mathrm{ml}$ )

b subtotal degranulation with accumulation of granules in perivascular area (arrow). Alloxan only (No. 15, glycaemia $174 \mathrm{mg} / 100 \mathrm{ml}$ )

e strong degranulation. In some cells there may still be seen granules (arrow); slight cytoplasmatic and nuclear vacuolization ( 2 arrows). Alloxan $50 \mathrm{mg} / \mathrm{kg}+$ pancreatectomy $50 \%$ (No. 91, glycaemia $299 \mathrm{mg} / 100 \mathrm{ml}$ ) Gomori-Runge stain; magnification $1175 \times$

largest diameter of the pituitary in one or two central sections. The cyclic or elliptic areas from these data were calculated. Since these diameters were measured in sections, they did not always represent the equatorial diameters and are only useful when compared with controls.

The pancreatic tissue was fixed in Bouin's solution, embedded in paraffin and the following stains used for this investigation: Aldehyde-fuchsin, Ponceau de $\mathrm{X}_{\mathrm{y}}$ lidine after Gomori-Runge, Hellerström's and Hellman's modification of Davenport's argentation, Tolui- animals the increase in body weight was slowed down markedly. In group 2, an average weight loss of $18.6 \mathrm{~g}$ resulted mainly from a marked weight loss in 2 animals that had a severe terminal infection (peritonitis or sublingual necrosis); whereas an average increase of $12 \mathrm{~g}$ in the 6 animals of group 1 resulted in part from 1 animal's increase of $30 \mathrm{~g}$; the other increases ranged between 0 and $10 \mathrm{~g}$. It is probable that with one exception the mouth trauma due to the i.v. sublingual injections was not responsible for the weight loss. The terminal weights of the control animals were not recorded. 
Fig. 2. Effect of repeated low doses of alloxan: Necrotic B-cells are scattered between apparently normal and vacuolized B-cells. (No. 17, terminal glycaemia : $136 \mathrm{mg} / 100 \mathrm{ml}$ ). Haematoxylin-Eosin; magnification $650 \times$

Fig. 3. Regeneration of islet cells with strands of cells showing dark nuclei and homogenous cytoplasm (arrow). On the other hand, completely degranulated Bcells with normally structured nuclei and vacuolated cytoplasm. Alloxan + pancreatectomy. (No. 94. glycaemia $294 \mathrm{mg} /$ $100 \mathrm{ml})$ Gomori-Runge stain; magnifi-

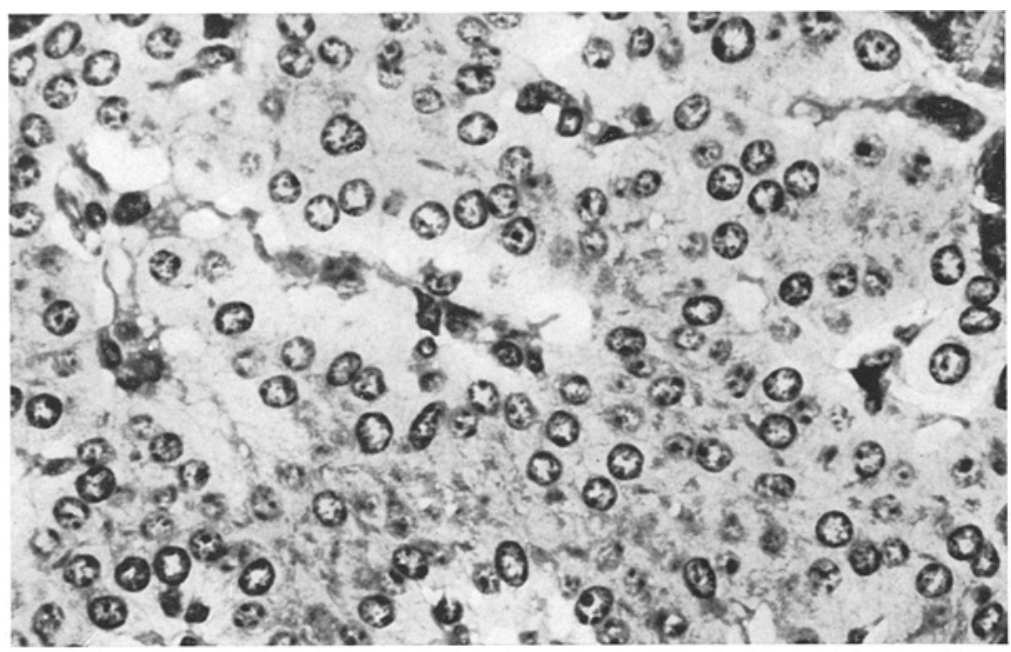
cation $925 \times$

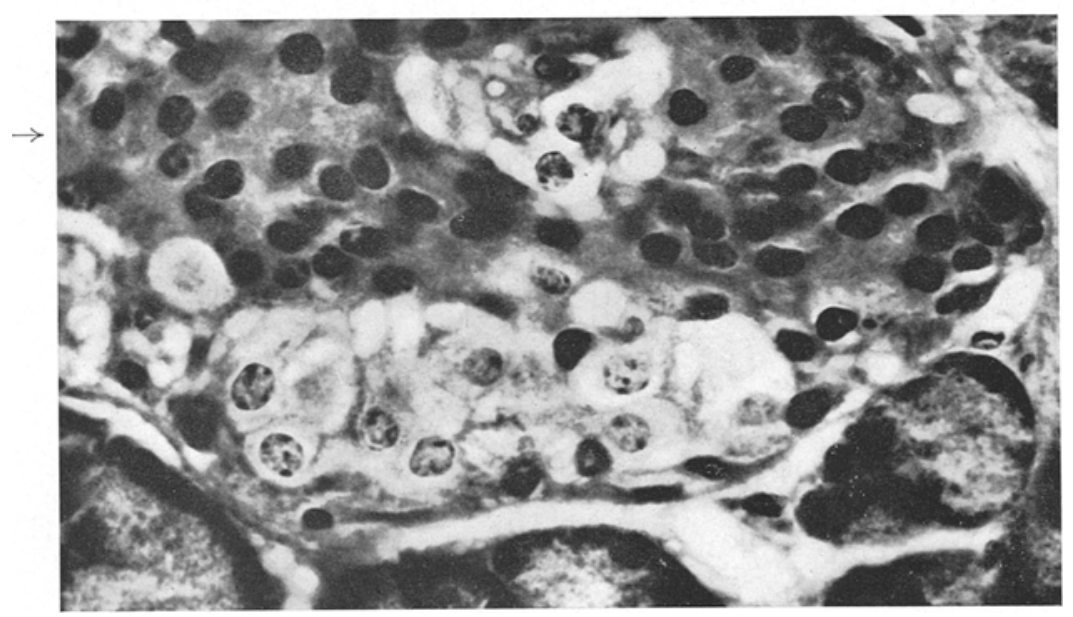

Table 1. Some data in the hyperglycaemic hamster series. The free fatty acids of the controls were measured in animals different from those in which the morphometric analyses were done. In group 1 hyperglycaemia is quite evident, and although it is not so marked in group 2 , the levels are quite different from those of the control group

\begin{tabular}{|c|c|c|c|c|}
\hline & $\begin{array}{l}\text { Group } 1(n=6) \\
\text { pancreatecto- } \\
\text { mized }(>50 \% \\
\text { of tissue) } \\
+ \text { alloxan }\end{array}$ & $\begin{array}{l}\text { Group } 2(n=9) \\
\text { alloxan } \\
\text { only }\end{array}$ & $\begin{array}{l}\text { Group } 3(n=6) \\
\text { controls }\end{array}$ & \\
\hline $\begin{array}{l}\text { Glucose (blood) } \\
\text { Free fatty acids } \\
\text { mean weight of } \\
\text { pituitariesa }\end{array}$ & $\begin{array}{r}269.3 \pm 29.5 \\
4.77 \pm 1.14 \\
7.65(n=3)\end{array}$ & $\begin{array}{c}153.3 \pm 19.2 \\
1.76 \pm 1.15 \\
3.0(n=2)\end{array}$ & $\begin{array}{c}114.3 \pm 15.9 \\
0.90 \pm 0.05 \\
2.5(n=4)\end{array}$ & $\begin{array}{l}\mathrm{mg} / 100 \mathrm{ml} \\
\mathrm{mval} / \mathrm{l} \\
\mathrm{mg}\end{array}$ \\
\hline
\end{tabular}

a only pituitaries without any hypothalamic tissue (histologically).

All the animals of group 1 and group 2 were slightly or moderately hyperglycaemic as shown in Table 1. In group 1, this hyperglycaemia and the rise in FFA were considerable. The pancreas morphology was consistent with B-cell hyperactivity and alloxan diabetes. There was almost total degranulation in the overwhelming number of B-cells (Figs. $1 \mathrm{c}, 2$ ), or they showed a striking orientation of the granules to the peri- capillary areas (Fig. 1 b); a few isolated B-cells with marked granulation were found in some islets. Ballooned cells were rather infrequent, whereas necrotic cells were numerous. In the liver cell nuclei, glycogen inclusions were not infrequent. In group 1, generally treated only once with alloxan, we observed definite signs of B-cell regeneration in some cases (Fig. 3). The islets showed marked hypertrophy and some of them 
showed considerable secretory activity. The Körnchen of Weichselbaum (stained with Toluidin blue) were elearly shown in most of the cases with hyperglycaemia. They were, however, present in one of the control cases (case 6) also. There was a slight elevation of the relative number of A-cells in the cases of groups 1 and 2 .

\section{Morphometric analysis of the pituitaries}

In hyperglycaemic animals we found a marked rise in the volume of acidophils (Fig. 4). The difference from

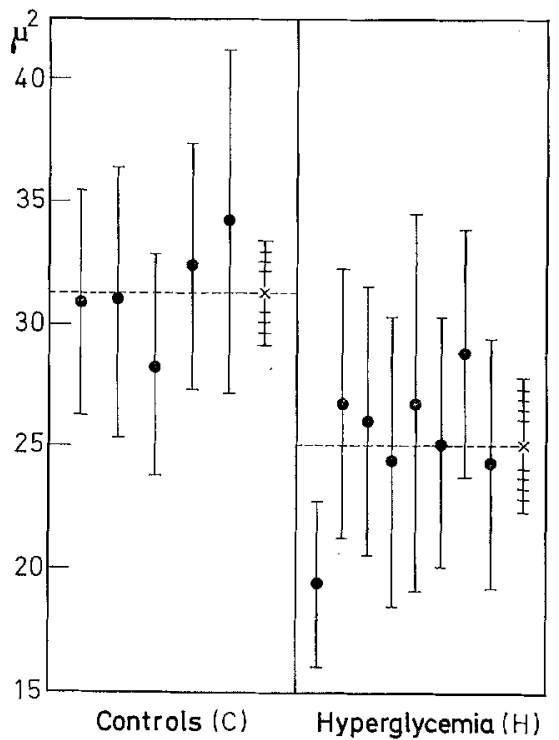

Fig. 4. Relative volume $(\%)$ of acidophilic cells in pituitaries of experimentally hyperglycaemie Syrian hamsters. Mean (volume \%): hyperglycaemic (6): $49.8+15.3$;

Controls (4): $17.3 \pm 5.65, p<0.005$ (Student's $t$ test)

the controls is statistically significant $(p<0.005)$, but there is no definite difference between severe and mild hyperglycaemia. (50.4 and $49.1 \%$ volume respectively). The lowest value was found in the pituitary of a glycosuric hamster suffering from a terminal peritoneal infection and a marked weight loss. Another glycosuric hamster, which could not be included in this series because it died $20 \mathrm{~h}$ after the first injection, had only $22.2 \%$ volume acidophils. This value is identical with those of the controls. Mitoses were not seen.

Karyometric studies (nuclei of acidophil cells in the pituitaries).

The results are shown in Fig. 5. Compared with those in the controls, the nuclei in the acidophil cells of both groups of hyperglycaemic animals had significantly smaller areas $(p<0.0025)$. The hyperglycaemic hamster with a terminal peritoneal infection had the smallest areas $(19.37 \pm 3.33)$. In the hyperglycaemic group, the prevalence of elliptic nuclei was obvious. In mucoid cells, diminution of the nucleic area was not seen; the impression was that larger areas prevailed.
The weights of the pituitaries (which histologically had shown pituitary tissue only) are listed in Table 1. The highest values were found in the definitely hyperglycaemic animals (group 1), whereas those of two animals of group 2 with slight hyperglycaemia were not significantly different from the controls. The weight increase correlated with the increase of the acidophil cell mass in 5 of the 6 hyperglycaemic cases.

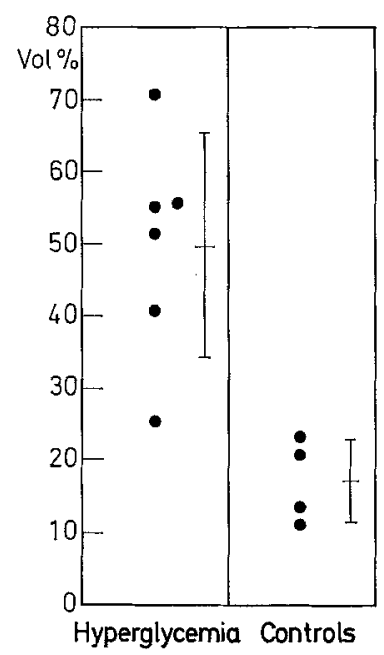

Fig. 5. Nuclear areas of pituitary acidophils in sections. The dots indicate the mean of 40 sequential areas of nuclei from acidophils found in the largest diameter of the central horizontal section of the pituitary. The data indicates the mean of the average areas and its standard deviation: hyperglycaemic (8 cases) : $25.01 \pm 2.75 \mu^{2}$; Controls (5 cases) : $31.29 \pm 2.17 ; t: 4.29, P<0.0025$

\section{Discussion}

In groups 1 and 2 a slight to marked hyperglycaemia and a rise of the FFA were obvious. Morphologically the islets showed the typical signs of a subdiabetic state according to Wellmann, Lazarus and Volk [22]. Necrosis of the B-cells was extended to a relatively moderate number, but a marked B-cell degranulation and hyperactivity was generally seen. This was demonstrated also by the presence of Weichselbaum's "Körnchen", which according to Gepts [3] are found in hyperactive B-cells. The possibility that the hyperglycaemic state resulted simply from the terminal ether narcosis or from a general toxic effect of alloxan could therefore be excluded. The evidence of B-cell regeneration and islet hyperplasia in group 1 , and the need for repeated injections of alloxan at various times in the experimental period in some of the animals, showed that B-cell activity was quantitatively somewhat disturbed. It did not show the common pattern of hyperactivity in every single case.

As in the pituitaries of lean or insulin-resistant human diabetics whom we had studied, there was a marked rise in the volume of the acidophils in the pituitaries of alloxan-diabetic Syrian hamsters with 
the exception of one cachectic animal. A similar finding was made by Gaunt, Bahn and Hayles [2] in pituitaries of newborns from diabetic mothers; the relative number of acidophils was not increased but the total volume was. In children with corticosteroid treatment, Montandon [10] made the same observation. Others have shown an elevated pituitary growth hormone content in corticosteroid-treated animals [9]. Hypercorticism is a known inducer of a relative insulin resistance and of tendency to hyperglycaemia. Therefore the common factor in diabetics, newborns of diabetic mothers and children under steroids would seem to be hyperglycaemia. We reviewed therefore the clinical data from the cases of our previous study [17], and saw that the patients of the first two groups (lean and insulin-resistant diabetics) had died almost without any exception after a diabetic coma or after a long-lasting postcomatous hyperglycaemic period; whereas in cases of obese diabetes death had generally occurred after cardiovascular complications. This increase in the mass of the pituitary acidophils in such cases is probably not the primary cause of the development of diabetes mellitus. An acidotic state as a possible inducer of this cytological change is not probable, and the general state of the animal and alloxan toxicity are at least in our cases of no major importance. The hamsters of group 1 seemed to be well, and showed even a slight increase in weight.

We should like to point out the increased weight of the pituitaries in the diabetic cases. We believe that it is a sex-independent reaction, which was not seen in the male and female controls. However, the number of cases is too small for a definite conclusion.

Many authors connect diminution of the nuclear volume and prevalence of elliptic areas, as shown in the pituitary acidophils, with decreased activity $[7,12$, $6,5]$.

This observation was also made when autoradiographic techniques were used $[12,18]$. The common factor effecting such a combination of decreased nuclear activity and increased total volume of the acidophils is probably an increased storage of cytoplasmic granules. Schelin, Lundin and Bartholdson [16], in another context, also thought that the presence of granules in the pituitary cell may reflect storage rather than secretion. On the other hand, degranulation may be in many cases a sign of activity, as in pituitary adenomas and in the pancreatic B-cells. With a few exceptions [19] this view is accepted by most authors.

These marked fluctuations in the cellular composition of the pituitary raise the question whether the cells of the anterior pituitary are capable of producing more than one single hormone when they are appropriately stimulated, or that the cell might have a capacity for storing more than one hormone. It is commonly accepted that growth hormone and prolactin are present in the acidophils $[4,13]$. In cases of genetic diabetes in mice [11] the granule increase could be paralleled with the growth hormone content. This hor- mone is rapidly secreted when hypoglycaemia, a stress or a rapid fall of hyperglycaemia occurs $[14,15]$; whereas it may decrease to immeasurably low plasma levels in the resting state or when a hypoglycaemic state is corrected. In our cases the chronic hyperglycaemia favours storage of growth hormone.

In conclusion we think that our findings of an elevation of the relative and absolute volumes of the acidophils in a diabetic state may be a secondary storage phenomenon induced by the chronic hyperglycaemia.

Acknowledgements. We wish to thank Misses Geneviève Borel and Erika Weber as well as Mr. Peter Schlosser for their technical assistance. Our gratitude goes to Prof. E.R. Weibel, Berne, for useful advice in stereological problems and to P.D. E.R. Froesch, Zurich, for providing the chemical data.

\section{References}

1. Feltkamp, C.A., Kwa, H.G.: Transformation of pituitary tumours from prolactin into TSH-cell types. I. Electron microscopical observations. Acta endocr. (Kbh.) Suppl. 100, 161 (1965).

2. Gaunt, W.D., Bahn, R.C., Hayles, A.B.: A quantitative cytologie study of the anterior hypophysis of infants born of diabetic mothers. Proc. Mayo Clin. 37, $345-353(1962)$.

3. Gepts, W.: Pathologic anatomy of the pancreas in juvenile diabetes mellitus. Diabetes 14, 619-633 (1965).

4. Hedinger, C.E., Farquhar, M.G.: Elektronenmikroskopische Untersuchungen von zwei Typen acidophiler Hypophysenvorderlappenzellen bei der Ratte. Schweiz. Z. Path. 20, 766-768 (1967).

5. Hellerström, C.: Effects of steroid diabetes on the pancreatic islets of guinea pigs with special reference to the $A_{1}$ cells. Acta Soc. Med. upsalien. 68, 1-16 (1963).

6. Hultquist, G.T.: Nuclear size in the cells of Langerhans islets during starvation in the rat. Acta anat. (Basel) 49, 281-287 (1962).

7. Kracht, J.: Morphologische Kriterien zur Beurteilung der Inselaktivität. Endokrinologie 36, 146-158 (1958).

8. Kwa, H.G., Feltkamp, C.A.: Transformation of pituitary tumours from prolactin-into TSH-cell type. II. Endocrine aspects. Acta endocr. (Kbh.) Suppl. 100, $162(1965)$.

9. Meyer, Y.N., Evans, E.S.: Acidophil regranulation and increased growth hormone concentration in the pituitary of thyroidectomized rats after cortisol administration. Endocrinology 74, 784-787 (1964).

10. Montandon, A.: Quantitative und qualitative Zellveränderungen im Hypophysenvorderlappen bei therapeutischem Hypercorticismus. Virchows Arch. path. Anat. 330, 629-650 (1957).

11. Nakamura, M., Yamada, K.: Studies on a diabetic (KK) strain of the mouse. Diabetologia 3, 212-221 (1967).

12. Oehlert, W., Schultze, B.: Die Kerngröße als Aus. druck der synthetischen Aktivität des Kerns. Beitr. path. Anat. 123, 101-113 (1960).

13. Pearse, A.G.E., van Noorden, S.: The functional cytology of the human adenohypophysis. Canad. med. Ass. J. 88, $462-471$ (1963).

14. Roth, J., Glick, S.M., Yalow, R.S., Berson, S.A.: Hypoglycemia: potent stimulus to secretion of growth hormone. Science 140, 987-988 (1963). 
15. Schalch, D.S.: The influence of physical stress and exercise on growth hormone and insulin secretion in man. J. Lab. clin. Med. 69, 256-269 (1968).

16. Schelin, U., Lundin, P.M., Bartholdson, L. : Light and electron microscopic studies on an autonomous stilboestrol-induced pituitary tumor in rats. Endocrinology 75, 893-900 (1964).

17. Steiner, H.: Quantitative und qualitative Zellveränderungen im Hypophysenvorderlappen bei Diabetes mellitus. Virchows Arch. path. Anat. 339, 171-186 (1965).

18. Stöcker, E., Dhom, G.: The nuclear RNA-Synthesis in the anterior pituitary of rats. Acta endocr. (Kbh.) Suppl. 100, 160 (1968).

19. Überberg, H.: Elektronenmikroskopische Untersuchungen am Hypophysenvorderlappen der Ratte. Endokrinologie 50, 290-297 (1966).
20. Weibel, E.R., Kistler, G.S., Scherle, W.F.: Practical stereological methods for morphometric cytology. J. Cell Biol. 30, $23-38$ (1966).

21. - Elias, H.: In: Quantitative Methods in Morphology, p. 3. Berlin, Heidelberg, New York: Springer 1967.

22. Wellmann, K.F., Brancato, P., Lazarus, S.S., Volk, B.W.: Rabbit beta cell ultrastructure and insulin radio-immunoassay in experimental subdiabetes. Arch. Path. 84, 251-263 (1967).

Dr. H. Steiner

Institut d'Anatomie Pathologique Université de Lausanne

19, rue de Bugnon.

CH-1011 Lausanne 